Int. J. Environ. Sci. Tech.

(C) Spring 2006, Vol. 3, No. 2, pp. 177-184

\title{
Cadmium absorption and accumulation in different parts of kidney beans, radishes and pumpkins
}

\author{
A. A. Azimi, ${ }^{*}$ T. Navab Daneshmand and A. Pardakhti \\ Department of Environmental Engineering, Graduate School of the Environment, Tehran University, Tehran, Iran
}

Received 13 Fenruary 2005;

revised 27 February 2006;

accepted 3 March 2006;

available online 20 April 2006

\begin{abstract}
This study is done to measure the absorption and distribution of cadmium in different parts of kidney beans, radishes and pumpkins. Three parts of a field was chosen. In one part 65 ppm of cadmium nitrate was added to water and in the other part $130 \mathrm{ppm}$, the last part was irrigated with normal water. Samples were digested by EPA 3050 method. Cadmium concentration was measured by Unicam 919 absorption unit. Beans accumulate cadmium mostly in root $(70 \mathrm{ppm})$ and a little amount is mobilized through upper parts (12-16ppm), but kidneys did not accumulate a significant amount. In radishes the roots did not accumulate a significant amount of cadmium but stems had 4 ppm and leaves had 25 ppm. Cadmium concentration in soil does not affect its concentration in different parts of pumpkins and beside the stems and leaves $(4 \mathrm{ppm})$ the other parts' concentrations were insignificant. In regard to the results of this study the cadmium concentrations in edible parts of the samples (kidney beans, radish roots and pumpkin fruit) were less than the U.S. EPA standards for agriculture and human beings.
\end{abstract}

Key words: Cadmium, kidney bean, radish, pumpkin, irrigation water

*Corresponding Author, E-mail: tala_navab@yahoo.com

\section{INTRODUCTION}

Cadmium is one of the trace elements in municipal wastewater which mostly accumulate in treated wastewater and sludge during the treatment process. If the treated wastewater effluent is used for irrigation, the amount of heavy metals in it should be controlled as plants accumulate different amounts of cadmium in regard to their types and environmental conditions (Doyle, 1998). Among heavy metals cadmium accumulates more in plants and by increasing the cadmium level in soil its concentration in plants increases significantly (Gardiner, et al., 1995). Cadmium accumulates in different parts of plants according to the plant type and high levels of cadmium in soil can reduce plant growth (Doyle, 1998). Cadmium accumulates in animal tissues as they eat plants which can cause problems for the animals. This element enters human's food chain directly or indirectly from plants or animals. Cadmium is a poisonous element which accumulates in body. Cadmium mostly makes complexes with metalothionin which separates in kidneys and accumulates in kidneys cortex. The malfunction of kidneys is the first indicator of cadmium poison.
Accumulation of more than $200 \mathrm{mg} / \mathrm{g}$ (of wet weight) of cadmium in kidneys cortex is poisonous. According to the World Health Organization, the acceptable level for weekly intake of cadmium is $7 \mathrm{mg} / \mathrm{g}$ of body weight. The continuous intake of cadmium may cause anemia which is because of decrease of ion adsorption by intestines. Furthermore intake of cadmium can cause itai-itai which is one of the results of osteoporosis (Carson, et al., 1986; CGER, 1996). The allowable amount of cadmium in sewage sludge for agricultural use is $85 \mathrm{mg} / \mathrm{kg}$ of soil and maximum of $39 \mathrm{mg} / \mathrm{kg}$ for monthly average in EPA part 503. Also the total cadmium amount applied to an acre should not increase $1.9 \mathrm{~kg}$ (EPA, 1995). The average dietary daily intake of cadmium has been estimated at 15-30 mg in England and maximum of $92 \mathrm{mg}$ in America (Doyle, 1998). The allowable amount reported by Iranian Environmental Protection Agency is $0.01 \mathrm{ppm}$ in treated wastewater for agricultural uses (Nourbakhsh and Ghazanfari Moghaddam, 2002). The allowable amount reported by Chaney is 0.5 ppm for human beings (Miller, 1995) and by Kabatta-Pendias is 10 to 20 ppm for animals in plants (Kabatta- Pendias and Pendias, 1992). 
This study was done to measure the absorption and distribution of cadmium in different parts of beans, radishes and pumpkins.

\section{MATERIALS AND METHODS}

Two pieces of a field were chosen where beans and pumpkins were planted in one of them and beans and radishes in the other one. The field was irrigated 3 times a week with the amount of $15 \mathrm{lit} / \mathrm{m}^{2}$. Cadmium nitrate, $\mathrm{Cd}\left(\mathrm{NO}_{3}\right)_{2}$ was used in the irrigation water for four months with the concentration of $65 \mathrm{ppm}$ in the first piece of the field and $130 \mathrm{ppm}$ in the second piece, other parts of the field were irrigated with normal water for controlling results. Also for controlling the results samples were taken from the soil and water of control samples. During the harvest good care was taken to have a good selection of the samples. After washing the samples, all parts of the crops were separated which included roots, stems, leaves, pods and kidneys of beans, roots, stems and leaves of radishes and stems, leaves, skin, fruit and seeds of pumpkins. For digestion of plants, water and soil samples standard 3050 of USEPA was used. After digestion the cadmium concentration of samples were measured by atomic absorption unit, Unicam 919 (EPA, 1995).

\section{RESULTS}

The results of the experiments over beans, radishes and pumpkins samples are in Tables 1, 2 and 3. The experiments show that the concentration of cadmium in soil and water of the control field were zero and $3 \mathrm{mg}$ /liter. The pH of the soil was 7.2 and the soil organic matter content was $3.5 \%$. Table 1 shows that cadmium accumulates significantly in beans. According to the third and fourth column of this Table, the concentration of cadmium does not change in roots, stems, leaves, pods and kidneys of beans when irrigated by water containing 65 ppm of cadmium in comparison to when irrigated by water containing $130 \mathrm{ppm}$ of this element. This shows that the concentration of a heavy metal in irrigation water can not be the only parameter to show the amount of absorption or the availability of the heavy metal (Ermst, 1996). In other words, in addition to the type of the plant and the concentration of the heavy metal in water or soil, absorption of heavy metals in plants depends on the degree of the elements dilution, which is related to the physical and chemical properties of the soil (Lasat, 2002 and Robinson, 1997). Results show that beans accumulate cadmium mostly in roots than in upper parts. The amount of cadmium accumulated in beans roots is high (about $70 \mathrm{mg} / \mathrm{liter}$ ), where the amount in stems leaves and pods is about 12 to $16 \mathrm{mg} /$ liter, but this ion does not appear in kidney beans. Kidneys are usually the only parts of the beans plants which people consume; therefore it may not be dangerous or unhealthy for the consumer. But it is better to control the use of beans when irrigated by water containing cadmium, so that according to the results of this study other parts of this plant would not be consumed. Table 2 shows the concentration of cadmium in roots, stems and leaves of radishes. This Table shows that Radish tops accumulate cadmium to a greater extent than do roots. In roots the amount of cadmium is not significant but in stems it is about 4 $\mathrm{mg} /$ liter where the concentration of this element in leaves is about $25 \mathrm{mg}$ /liter which indicates the cadmium is not immobilized in the root but is translocated to the above ground parts of the plant. The main edible part of radish plants is its roots but as the leaves are consumed by many people, according to the results of

Table 1: cadmium concentration in different parts of beans irrigated by normal water and water with cadmium

\begin{tabular}{clll}
\hline Plant parts & \multicolumn{3}{c}{ Cadmium concentration in irrigation water $(\mathrm{mg} / \mathrm{L})$} \\
\hline & 3 (normal water) & \multicolumn{1}{c}{65} & \multicolumn{1}{c}{130} \\
\multirow{2}{*}{ roots } & ${ }^{*} 0.78 \pm 0.14$ & $70.70 \pm 5.69$ & $70.56 \pm 4.32$ \\
& $($ No. $=6)$ & $($ No. $=6)$ & (No.=6) \\
stems & $1.82 \pm 0.58$ & $14.13 \pm 1.69$ & $14.71 \pm 2.28$ \\
& $($ No. $=6)$ & $($ No. $=9)$ & (No.=6) \\
leaves & $2.35 \pm 0.20$ & $15.54 \pm 1.19$ & $16.03 \pm 0.28$ \\
& $($ No. $=6)$ & $($ No. $=6)$ & (No.=18) \\
pods & $0.95 \pm 0.24$ & $12.11 \pm 0.51$ & $12.96 \pm 1.25$ \\
& $($ No. $=6)$ & $($ No. $=6)$ & $($ No. $=6)$ \\
kidneys & $0.40 \pm 0.14$ & $0.79 \pm 0.01$ & $0.68 \pm 0.03$ \\
& $($ No. $=6)$ & $($ No. $=6)$ & $($ No. $=12)$ \\
\hline
\end{tabular}

* Medium \pm standard deviation 
Table 2: cadmium concentration in different parts of radishes irrigated by normal water and water with cadmium

\begin{tabular}{cll}
\hline & \multicolumn{1}{c}{ Cadmium concentration in irrigation water $(\mathrm{mg} / \mathrm{L})$} \\
\hline Plant parts & 3 (normal water) & \multicolumn{1}{c}{130} \\
roots & $* 0.84 \pm 0.04$ & $2.57 \pm 1.14$ \\
& $($ No. $=6)$ & $($ No. $=6)$ \\
\multirow{2}{*}{ stems } & $1.33 \pm 1.89$ & $4.08 \pm 1.63$ \\
& $($ No. $=6)$ & $($ No. $=12)$ \\
leaves & $2.64 \pm 0.71$ & $25.81 \pm 1.75$ \\
& $($ No. $=6)$ & $($ No. $=6)$ \\
\hline
\end{tabular}

* Medium \pm standard deviation

Table 3: cadmium concentration in different parts of radishes irrigated by normal water and water with cadmium

\begin{tabular}{cll}
\hline & \multicolumn{2}{c}{ Cadmium concentration in irrigation water $(\mathrm{mg} / \mathrm{L})$} \\
\hline Plant parts & \multicolumn{1}{c}{3 (normal water) } & \multicolumn{1}{c}{130} \\
\multirow{2}{*}{ stems } & $1.35 \pm 0.75$ & $4.5 \pm 1.73$ \\
& $($ No. $=6)$ & $($ No. $=6)$ \\
leaves & $1.82 \pm 0.72$ & $3.8 \pm 0.36$ \\
& $($ No. $=18)$ & $($ No. $=24)$ \\
skin & $0.1 \pm 0.03$ & $1.51 \pm 0.45$ \\
& $($ No. $=6)$ & $($ No. $=6)$ \\
fruit & $0.34 \pm 0.01$ & $1.04 \pm 0.22$ \\
& $($ No. $=6)$ & $($ No. $=9)$ \\
seeds & $0.1 \pm 0.05$ & $0.18 \pm 0.24$ \\
& $($ No. $=6)$ & $($ No. $=6)$ \\
\hline
\end{tabular}

this study it is safe to control the use of radishes where they are irrigated by water containing cadmium for not eating the leaves. In such case the leaves can be separated before the access of people to it.

Table 3 shows that presence of cadmium in soil has an insignificant effect on the cadmium concentration in different parts of pumpkins. In fact beside the stems and leaves of pumpkins which accumulate about $4 \mathrm{mg} /$ liter of this element when irrigated by water containing 65 ppm of cadmium other parts of this plant does not contain significant amounts of this ion. The results show that cadmium does not enter pumpkin fruits and it is only seen in leaves and stems in little amounts.

\section{DISCUSSIONAND CONCLUSION}

Beans accumulate cadmium mostly in roots and the amount of this ion in stems, leaves and pods is also significant. As the main edible parts of beans are the kidney beans therefore it may not be dangerous or unhealthy for the consumer. It is also recommended to separate beans roots when using for animal food.

Cadmium ion is translocated to the upper parts of the radish plant after absorption and as radish roots are consumed mostly there may not be any problem. But in case of high concentration of cadmium in soil the use of leaves and stems of radishes is not recommended either for people or animals. Pumpkins do not accumulate cadmium significantly and therefore consuming the fruit of this plant which is probably the only edible part of it is safe for people and the remaining parts may also be used for animal food.

\section{REFERENCES}

Anonymous, U. S. Environmental Protection Agency, 1995. Process Design Manual: Land application of sewage sludge and domestic septage, EPA/625/R-95/001, Washington.

Anonymous, U. S. Environmental Protection Agency, (1995). Test methods for the evaluating solid waste, SW-846, Office of Solid Waste and Emergency Response, Washington.

Anonymous, Commission on geosciences, Environmental and Resources (CGER), (1996). Useof Reclaimed Water and Sludge in food Crop Production, National Academic Press, Washington, DC.

Doyle, P. J., (1998). Survey of literature and experience on the disposal of sewage on land. (Accessed 10 February 2005), Available from: http://www.ecobody.com/reports/sludge/ dole_report VpToc.htm

Ermst, W. H. O., (1996). Bioavailability of heavy metals and decontamination of soil by plants, Appl. Geochem., 11 (1): 
163-167.

Gardiner, D. T., Miller, R. W., Badamchian, B., Azzari, A. S. and Sisson, D. R., (1995). Effects of repeated sewage sludge applications on plant accumulation of heavy metals. Agri. Eco. Environ., 55, 1-6.

Kabata-Pendias, A. and Pendias, H., (1992). Trace elements

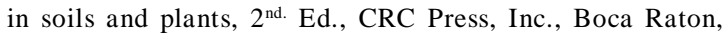
Florida.

Lasat, M. M., (2002). The use of plants for the removal of toxic metals from contaminated soils: 2002011154, U. S. environmental agency.

Miller, R. W., Al-Khazraji, M. L., Sisson, D. R. and Gardiner, D. T., (1995). Alfalfa growth and absorption of cadmium and zinc from soils amended with sewage sludge. Agri. Eco. Environ., 53, 179-184.

Nourbakhsh, Sh., Ghazanfari Moghaddam, A., (2001). Effect of heavy metals in soil on growth and edible parts of plants, Fourth Environmental Sanitary Congress, Shahid Saddoughi University, Yazd, Iran, 7-15.

Robinson, B. H., (1997). The phytoextraction of metals from metalliferous soils, Ph.D. Thesis, Massy University, New Zealand.

Anonymous, U. S. Environmental Protection Agency, (1995). Test methods for the evaluating solid waste, SW-846, Office of Solid Waste and Emergency Response, Washington.

\section{AUTHOR(S) BIOSKETCHES}

Azimi, A. A., Associate Professor., Department of Environmental Engineering, University of Tehran, Tehran, Iran. E-mail: aaazimi@chamran.ut.ac.ir

Navab Daneshmand, T., M.Sc., Department of Environmental Engineering, University of Tehran, Tehran, Iran. E-mail: talannavab@yahoo.com

Pardakhti, A., M.Sc., Instructor of Biological Sciences, Department Environmental Engineering, University of Tehran, Tehran, Iran. E-mail:arparda@yahoo.com

\section{This article should be referenced as follows:}

Azimi, A. A., Navab Daneshmand, T. and Pardakhti, A., (2006). Cadmium absorption and accumulation in different parts of kidney beans, radishes and pumpkins. Int. J. Environ. Sci. Tech., 3 (2),177-180. 